\title{
Improvement of $\mathrm{VO}_{2}$ max in Patient with Restrictive Pulmonary Disorder after Deep Breathing Exercise
}

\author{
Lisa Nurhasanah, Erna Setiawati, Rahmi Isma AP
}

Department of Physical Medicine and Rehabilitation, University of Diponegoro, Semarang, Indonesia

\begin{abstract}
Introduction: Restrictive pulmonary disorder is reducing $\mathrm{VO}_{2}$ max values. It can be caused by lung can't take oxygen from outside air freely. Pulmonary rehabilitation is known to increase the $\mathrm{VO}_{2}$ max. One of the pulmonary rehabilitation is deep breathing exercise. In this study aimed to know the improvement VO2 max after deep breathing exercise.

Methods: This was an experimental without control pre and post-experimental study. The Six Minutes Walking Test (6MWT) was measured in patients with restrictive pulmonary disorder, after deep breathing exercise two times a day, for four weeks in May 2018.

Results: Fifteen subjects were recruited, with the mean age was 70,76 $\pm 5,33$ years old, 6MWT was $375,13 \pm 44,19 \mathrm{~m}$ and $\mathrm{VO}_{2} \operatorname{Max} 31,61 \pm 0,86 \mathrm{ml} / \mathrm{kg} /$ minute. After four weeks intervention, 6MWT value was $401 \pm 44,57 \mathrm{~m}(\mathrm{p}=0.000)$ and $\mathrm{VO}_{2}$ Max score was $32,11 \pm 0,87 \mathrm{ml} / \mathrm{kg} /$ minute $(\mathrm{p}=0.000)$.
\end{abstract}

Conclusion: Four weeks of deep breathing exercise can improve the $\mathrm{VO}_{2}$ max in restrictive lung disorder.

Keywords: Deep breathing exercise, Restrictive pulmonary disorder, $\mathrm{VO}_{2}$ max. 


\begin{abstract}
ABSTRAK
Pendahuluan: Terjadi penurunan $\mathrm{VO}_{2}$ maks pada penyakit paru restriktif, yang disebabkan organ paru tidak dapat menangkap oksigen dengan leluasa. Tatalaksana Rehabilitasi Paru diharapkan dapat meningkatkan $\mathrm{VO}_{2}$ maks. Salah satu tindakan rehabilitasi paru-paru adalah latihan nafas dalam. Penelitian ini bertujuan untuk mengetahui perbaikan $\mathrm{VO}_{2}$ maks setelah latihan nafas dalam.

Metode: Desain pre dan post intervensi tanpa kontrol. Peneliti melakukan penilaian uji jalan Enam Menit (Six Minutes Walking Test - 6MWT) pada pasien dengan penyakit paru-paru restriktif, sebelum dan setelah latihan nafas dalam, dua kali sehari, selama empat minggu, pada bulan Mei 2018.
\end{abstract}

Hasil: Lima belas subjek direkrut, dengan usia rata-rata 70,76 \pm 5,33 tahun, 6MWT adalah 375,13 \pm 44,19 m dan $\mathrm{VO}_{2}$ Max 31,61 $\pm 0,86 \mathrm{ml} / \mathrm{kg} / \mathrm{menit}$. Setelah empat minggu intervensi, nilai $6 \mathrm{MWT}$ adalah $401 \pm 44,57 \mathrm{~m}$ $(\mathrm{p}=0.000)$ dan skor $\mathrm{VO}_{2}$ Max adalah $32,11 \pm 0,87 \mathrm{ml} / \mathrm{kg} / \mathrm{menit}(\mathrm{p}=0.000)$.

Kesimpulan: Latihan nafas dalam secara teratur selama empat minggu, dapat memperbaiki $\mathrm{VO}_{2}$ maks pada penyakit paru restriktif.

Kata kunci: Latihan Nafas Dalam, Penyakit Paru Restriktif, $\mathrm{VO}_{2}$ maks

\section{Correspondent Detail:}

\section{Lisa Nurhasanah}

Email: lisanurhasanah.dr@gmail.com

Phone: 082114618086

Department of Physical Medicine and

Rehabilitation, University of Diponegoro,

Semarang, Indonesia

\section{INTRODUCTION}

In restrictive pulmonary disorders, there are several common manifestations, such as dyspnea, fatigue, and inactivity. In addition, patients sometimes complain of heart problems, muscle disorders, nutritional problems, and psychological problems that stand alone or in combination with respiratory disorders. Overall this affects the quality of life of both private patients and also families.

Restrictive pulmonary disorders are disorders that occur in the lung parenchyma or can also be caused by disorders outside the lungs (pleura, chest wall and neuromuscular). This condition is characterized by a decrease in lung volume due to decreased compliance of the lung and chest wall so that oxygen levels that can be taken are also reduced. ${ }^{1-3}$

The causes of restrictive pulmonary disorder can be divided into two groups based on anatomy structure. The first is intrinsic disorder (i.e. diseases involving lung parenchyma that cause the lungs to not develop fully such as idiopathic fibrosis, the usage of drugs, exposure to inorganic and organic dust). The second is extrinsic disorder (i.e thoracic wall nonmuscular diseases, neuromuscular and pleural disorders). ${ }^{1,3,4}$ 
Restrictive pulmonary disorder caused by intrinsic disorders, physiological abnormalities that occur in the form are poor diffusion capacity, poor pulmonary compliance, and pulmonary hypertension in later disease. In restrictive pulmonary disorder caused by extrinsic disorders, physiological abnormalities that occur are poor chest wall compliance, chest wall muscle weakness, loss of neural control of breathing musculature. ${ }^{2,4,6}$

In the United States, intrinsic pulmonary disorders with a prevalence of 3-6 cases per 100,000 population. Prevalence of Idiopathic Pulmonary Fibrosis (IPF) 27-29 cases per 100,000 people, aged between 35-44 years. The prevalence at the age of $>75$ years increases by 175 cases per 100,000 people. Predictions for mortality are: old age, male, poor lung function, severity of fibrosis, weak response to therapy, presence of fibroplasia in histopathology. Based on race, it was reported that white people with sarcoidosis in the US had a risk of 10-17 times compared to blacks. ${ }^{4}$

Symptoms and signs that are usually found in restrictive pulmonary disorder are shortness of breath, dyspneu, dry cough, easy fatigue, difficulty in removing secretions or kyphoscoliosis, tachypneu, reduced exercised tolerance. Other symptoms and signs following the underlying disease. ${ }^{1,4}$

Pulmonary function test is a supports examination to determine the restrictive pulmonary disorder. It is using the Spirometer test. In restrictive pulmonary disorder, there are a decrease in Total Lung Capacity (TLC), Functional Residual Capacity (FRC) and Residual Volume (RV). Decreased Forced Expiratory Volume in one second (FEV1) and Forced Vital capacity (FVC) with normal values or an increase in the ratio of FEV1 to FVC indicates a restrictive pulmonary disorder condition. ${ }^{4,6}$

Restrictive pulmonary disorders can affect daily activities because they will progressively decrease fitness and functional abilities. $\mathrm{VO}_{2}$ max is one of the standards for assessing physical fitness which is affected by oxygen intake, oxygen delivery and oxygen using. The 6 Minutes Walking Test (6MWT) is a test that can be done to find out $\mathrm{VO}_{2}$ max. Fatemi et al. in their study found a significant difference $(p<0.001)$ for lung function as assessed through FEV1, FVC and FVE1 / FVC values from 51 subjects divided into three levels groups of $\mathrm{VO}_{2}$ max and in their study it can be concluded that the higher the lung function value, the higher the $\mathrm{VO}_{2}$ max value of a person. ${ }^{1,3}$

There are treatments for restrictive pulmonary disorder, i.e. Corrective measures (e.g., appropriate antibiotic for infection, treatment of pleura effusion, etc); Supportive measures like supplemental oxygen, nutritional and ventilatory support; Physical therapy; Pulmonary rehabilitation. ${ }^{1,4}$

Pulmonary rehabilitation in restrictive pulmonary disorders consists of strength training of respiratory muscles, cardiopulmonary endurance exercises, breathing exercises and education in disease and home programs. Tonelli et al. (2017) on forty-one patients (IPF 63\%, age 66.9 $\pm 11 \mathrm{ys})$ were enrolled in a standard pulmonary rehabilitation course in two centers. From forty one patients, $97 \%(n=40)$ completed the program. Exercise performance (both at peak load and submaximal effort), symptoms (iso-time dyspnea and leg fatigue), quality of life (St. George Respiratory Questionnaire-SGRQ) and chronic dyspnea (Medical Research Council scale- 
MRC) significantly improved after pulmonary rehabilitation $(\mathrm{p}<.001)$. Patients with lower baseline 6MWT showed greater improvement in 6MWT (Spearman r score $=-.359, \mathrm{p}=.034$ ) and symptoms relief at SGRQ $(\mathrm{r}=-.315, \mathrm{p}=.025)$ regardless of underlying disease. It similar with Huppmann et al study on four hundred and two consecutive ILD patients who were admitted to a specialised pulmonary rehabilitation centre (1999-2010). ${ }^{7,8}$

Deep breathing exercise is a part of pulmonary rehabilitation. It is an easy alternative program for patients that can be used as a home program. Deep breathing is a slowly and deeply breathing technique which is taught to conscious and cooperative clients. The purposes of deep breathing exercise is to increase the oxygen intake. It is allowing abdomen lifts slowly and chest fully expands, increase maximal alveolar inflation, increase muscle relaxation, improve effective coughing mechanisms, prevent atelectasis, increase the strength of respiratory muscles, mobility of the chest and thoracic vertebr, also correct abnormal breathing patterns. ${ }^{3,9,10}$

Deep breathing exercise will improve compliance of the lung parenchyma and respiratory muscles so that it will increase oxygen intake into the body. With the increase in oxygen intake will increase the circulation of oxygen into the blood carried to the muscles. In the muscles, oxygen will be used by the mitochondria. The more increased oxygen intake to the mitochondria the better the muscle performance. One of them is the lower limb muscles used for the 6 minute walk test. An experimental study by Hyun Gyu Cha et al (2016) on the elderly proved to be an increase in lung function and distance in 6MWT after being given a deep breathing exercise for four weeks. ${ }^{8,9}$
In this study, researchers want to find out the improvement of $\mathrm{VO}_{2}$ max in patients with restrictive pulmonary disorder who get only four weeks deep breathing exercise.

\section{METHODS}

This study was an experimental without control pre and post-experimental study. The method of sampling is the total sample in which all patients who meet the inclusion and exclusion criteria are included. Data was taken at the Pucang Gading social rehabilitation clinic in May 2018. We took data on restrictive pulmonary disorder patients who received deep breathing exercise therapy conducted twice a day for four weeks interventions. Before the intervention begins the patient is trained first by the physiatrist. When the implementation is guided by officers from the clinic.

Inclusion criteria were people having mild to moderate restrictive pulmonary disorders assessed from spirometry results, able to understand instructions, able to walk without assistance and willing to be included in the study by filling the informed consent. Exclusion criteria were the presence of illness that makes the patient impossible to take part in the study. And the drop out criteria: participants refuse to continue the training session until completion, attendance is less than $80 \%$.

The Stages of deep breathing exercise were: ${ }^{1,4}$ The patient sits upright in a chair and place their hand above the abdomen (just below the ribs) and in the middle of the chest. The patient has to feel the movements of chest and abdomen when they are breathing; The doctor was asking the patients to take a deep breath through the nose for four seconds 
until the chest and abdomen feel lifted up, and then keep the mouth closed during inspiration, hold the breath for two seconds then exhale through the lips that are pressed together and slightly open while tightening (contracting) the muscles abdomen in 4 seconds. This step must be repeated three times for a minute with a two second break on each repetition, and then it's followed by a two minute rest period. This exercise is called a cycle. The exercise has to twice a day.

$\mathrm{VO}_{2}$ max data were taken from the assessment 6 MWT before and after the intervention under physiatrist supervision. The 6MWT is a simple, practical test that requires a 100 -foot (30-meters) track that does not require complicated training equipment or experienced personnel and special training. But now with the Nury tract the distance can be reduced to 15 meters. This coupled with the three-step rotational method has been shown to be statistically not significantly different from walking straight. ${ }^{9-11}$

This test measures the distance that patient can travel by walking on a flat track and hard surface within 6 minutes. This test as a whole evaluates the response of all organ systems involved during exercise including the pulmonary, cardiac and circulatory systems, blood, neuromuscular and muscle metabolism. ${ }^{11}$

\section{Statistical Analysis}

Statistical analysis was using IBM SPSS for Windows version 25. To evaluate the distributions of numeric data it's using Kolmorogov-Smirnov normality test for numerical data, if the data is normally distributed the hypothesis test for the mean difference between the two groups. If the data distribution is normal uses paired t test or Wilcoxon test if the data distribution is not normal. Significance in this study was obtained if $p$ values $<0.05$ were obtained with $95 \%$ confidence intervals.

\section{RESULTS}

Fifteen subjects were recruited, with the mean age was 70,76 $\pm 5,33$ years old, $6 \mathrm{MWT}$ was $375,13 \pm 44,19 \mathrm{~m}$ and $\mathrm{VO}_{2} \operatorname{Max} 31,61 \pm 0,86 \mathrm{ml} /$ $\mathrm{kg} /$ minute. The subject's baseline characteristic can be seen in table 1 .

Table 1. Baseline Characteristic

\begin{tabular}{cc}
\hline Baseline characteristic & Mean $\pm \mathrm{SD}$ \\
\hline Age (years) & $70,67 \pm 5,33$ \\
6MWT (meter) & $375,13 \pm 44,19$ \\
$\mathrm{VO}_{2} \mathrm{Max}(\mathrm{ml} / \mathrm{kg} /$ minute) & $31,61 \pm 0,86$ \\
\hline
\end{tabular}

After four weeks intervention, 6MWD value was $401 \pm 44,57 \mathrm{~m}(\mathrm{p}=0,000)$, ad $\mathrm{VO}_{2}$ max score was $32,11 \pm 0,87 \mathrm{ml} / \mathrm{kg} /$ minute $(\mathrm{p}=0,000)$. There were improvement in $6 \mathrm{MWD}$ and $\mathrm{VO}_{2}$ Max after the intervention can be seen in table 2 .

Table 2. Comparison in $6 \mathrm{MWT}$ and $\mathrm{VO}_{2} \mathrm{Max}$ after deep breathing exercise

\begin{tabular}{lccc}
\hline Baseline characteristic & Before & After & p \\
\hline $6 \mathrm{MWT}($ meter $)$ & $375,13 \pm 44,19$ & $401 \pm 44,57$ & 0,000 \\
$\mathrm{VO}_{2} \max (\mathrm{ml} / \mathrm{kg} /$ minute $)$ & $31,61 \pm 0,86$ & $32,11 \pm 0,87$ & 0,000 \\
\hline
\end{tabular}




\section{DISCUSSION}

The participant in this study are fifteen patients with restrictive pulmonary disorder at Pucang Gading social rehabilitation clinic. The highest restrictive pulmonary disorder prevalence is more than 75 years old. It's similar with the mean age of the participants in this study which is 70 years old. ${ }^{3}$

The fifteen participants received interventions in the form of deep breathing exercise conducted twice a day for four weeks. Before the intervention begins the patient is trained first by the physiatrist. When the implementation is guided by officers from the clinic. $\mathrm{VO}_{2}$ max data were taken from the assessment 6 MWT before and after the intervention under physiatrist supervision.

Restrictive pulmonary disorder is caused by a decrease in recoil of the lungs and chest wall or in other words a person with this conditon can not develop the lungs fully so that the amount of oxygen taken during the inhalation process also decreases. Signs and symptoms that occur in patients with restrictive pulmonary disorders often include shortness of breath, easy fatigue and reduced exercise tolerance. Breathing exercise can increase the ability of lung development so tissue's oxygen supply will be adequate by improve ventilation. This has been proven in research by Fatemi et al on population with three stage of lung function (mild, moderate and severe) who concluded that the higher the lung function value, the higher the $\mathrm{VO}_{2}$ max value of a person. ${ }^{1,2}$

In this study there was a significant increase in the results of the 6MWT assesement and $\mathrm{VO}_{2}$ max. In other words it can be concluded that the average patient can walk 26 meters further in 6 MWT assesment after the intervention. These results are simillar with previous studies by Fatemi et all and Hyun Gyu Cha et all and Huppmann et al study on four hundred and two consecutive ILD patients who were admitted to a specialised pulmonary rehabilitation centre (1999-2010) that the 6MWT distance improved by 46,3 $\mathrm{m}$ (308,6 $\mathrm{m}$ versus $354,6 \mathrm{~m} ; \mathrm{p}, 0.001) .,{ }^{2,6,8}$

\section{CONCLUSION}

In summary, four weeks deep breathing exercise for restrictive pulmonary disorder patients improve the $\mathrm{VO}_{2}$ Max.

\section{REFERENCES}

1. Illi SK, HeldU, FrankI.Effect of respiratory muscle training on exercise performance in healthy individuals: a systematic review and meta-analysis. Spengler CM. Sports Med. 2012; 42(8):707-24

2. Fatemi R, Shakerian S, Ghanbarzade M, Habibi A. The comparison of dynamic volumes of pulmonary function between different levels of maximal oxygen uptake. Int Res J Appl Basic Sci. 2012; 3(3): 66774. Available at: http://www.irjabs.com/ files_site/paperlist/r_345_121110003253. pdf. Accessed August 30, 2019.

3. Caronia JR. Restrictive Lung Disease Clinical Presentation. 2019. Available at: https://emedicine.medscape.com/ article/301760-clinical\#b1. Accessed August 30, 2019.

4. Shneerson JM. In: Pulmonary Rehabilitation. Rehabilitation in thoracic wall deformities. Newyork: Oxford 
University Pres; 2015. 270-2.

5. Kagaya H, Takahashi H, Sugawara K. Effective Home-Based Pulmonary Rehabilitation in Patients with Restrictive Lung Diseases. Tohoku J Exp Med. 2009; 215-9. Available at: https://www.ncbi. nlm.nih.gov/pubmed/19561392. Accessed August 30, 2019.

6. Tonelli R, Conccooncelli E, Lanini B, Romagnoli I, Florini F, Castaniere I, et al. Effectiveness of pulmonary rehabilitation in patients with interstitial lung disease of different etiology: a multicenter prospective study. BMC Pulmonary Medicine. 2017; 17: 130-8. Available at: https://www.ncbi.nlm.nih.gov/ pubmed/29017478. Accessed August 30, 2019.

7. Huppmann P, Sczepanski B, Boensch M, Winterkamp S, Schonheit-Ken U, Neurohr C, et al. Effects of inpatient pulmonary rehabilitation in patients with interstitial lung disease. European Respiratory Journal. 2013; 42: 444-53. Available at: https://erj.ersjournals.com/ content/42/2/444.article-info. Accessed August 30, 2019.

8. Cha H, Choe Y, Kim M. The Effects of Air Stacking Exercise on Pulmonary Function in Elderly Adults.J Korean Soc Phys Med. 2016; 11(4): 55-64. Available at: https:// pdfs.semanticscholar.org/f963/b226df8 af79f9f4803cbba3743130233c7cc.pdf.
Accessed August 31, 2019.

9. Raichlen, D.A., Klimentidis, Y.C., Bharadwaj, P.K. et al. Differential associations of engagement in physical activity and estimated cardiorespiratory fitness with brain volume in middleaged to older adults. Brain Imaging and Behavior.2019: 1-10. https://doi. org/10.1007/s11682-019-00148-x

10. Boushel R, Ara I, Gnaiger E, Helge JW, González-Alonso J, Munck-Andersen T, Sondergaard H, Damsgaard R, van Hall G, Saltin B, et al. Low-intensity training increases peak arm $\mathrm{VO} 2$ by enhancing both convective and diffusive $\mathrm{O} 2$ delivery. Acta Physiol (Oxf). 2014; 211(1):122-34.

11. Nusdwinuringtyas N, Widjajalaksmi W, Yunus F, Alwi A. Reference Equation for Prediction of a Total Distance during Six-Minute Walk Test Using Indonesia Anthropometrics. Jakarta: Acta Medica Indonesiana 2014; 46 (2): 90-6. Avalaible at: https://www.ncbi.nlm.nih.gov/ pubmed/25053680. Accessed August 31, 2019.

12. Kamiya K, Hamazaki N, Matsue $\mathrm{Y}$, Mezzani A, Corrà U, Matsuzawa R, et.al. Gait speed has comparable prognostic capability to six-minute walk distance in older patients with cardiovascular disease. Eur J Prev Cardiol. 2018 ;25(2):212-219. doi: $10.1177 / 2047487317735715$. 